\title{
Nutrient density of beverages in relation to climate impact
}

\author{
Annika Smedman 1,2*, Helena Lindmark-Månsson ${ }^{2,3}$, \\ Adam Drewnowski ${ }^{4}$ and Anna-Karin Modin Edman' ${ }^{2}$
}

'Unit for Clinical Nutrition and Metabolism, Department of Public Health and Caring Sciences, Uppsala University, Uppsala, Sweden; '2Department of Research and Development, Swedish Dairy Association, Sweden; ${ }^{3}$ Department of Food Technology, Engineering and Nutrition, Lund University, Lund, Sweden; ${ }^{4}$ Center for Public Health Nutrition and the Nutritional Sciences Program, School of Public Health, University of Washington, Seattle, WA, USA

Abstract

The food chain contributes to a substantial part of greenhouse gas (GHG) emissions and growing evidence points to the urgent need to reduce GHGs emissions worldwide. Among suggestions were proposals to alter food consumption patterns by replacing animal foods with more plant-based foods. However, the nutritional dimensions of changing consumption patterns to lower GHG emissions still remains relatively unexplored. This study is the first to estimate the composite nutrient density, expressed as percentage of Nordic Nutrition Recommendations (NNR) for 21 essential nutrients, in relation to cost in GHG emissions of the production from a life cycle perspective, expressed in grams of $\mathrm{CO}_{2}$-equivalents, using an index called the Nutrient Density to Climate Impact (NDCI) index. The NDCI index was calculated for milk, soft drink, orange juice, beer, wine, bottled carbonated water, soy drink, and oat drink. Due to low-nutrient density, the NDCI index was 0 for carbonated water, soft drink, and beer and below 0.1 for red wine and oat drink. The NDCI index was similar for orange juice (0.28) and soy drink (0.25). Due to a very high-nutrient density, the NDCI index for milk was substantially higher $(0.54)$ than for the other beverages. Future discussion on how changes in food consumption patterns might help avert climate change need to take both GHG emission and nutrient density of foods and beverages into account.

Keywords: nutrient density; nutrition, nutrition recommendations; climate change; greenhouse gas (GHG) emissions

Received: 26 March 2010; Revised: 24 June 20I0; Accepted: 6 July 2010; Published: 23 August 2010

$\mathrm{C}$ limate change has gained political importance over the last few years. Accumulated scientific evidence indicates that the climate situation is, in fact, alarming and reductions in greenhouse gas (GHG) emission are urgent (1).

For an average citizen of Sweden, annual food consumption contributes about $25 \%$ of the total GHG emissions (2). In the European Union about $31 \%$ of total GHG emissions are estimated to come from the food chain (3). Discussions on how to reduce food-related GHG emissions have focused both on modifying the food production and supply chain and on modifying demand through significant changes in food consumption patterns. Such discussions have taken place in the UK and in Switzerland $(4,5)$, within the United Nations Food and Agricultural Organization (FAO) (6) and among other international agencies such as the United Nations Environmental Programme (UNEP) (7). In Sweden, the National Food Administration has aligned nutrition recommendations with environmental concerns (8), and further actions to reduce climate effects are demanded within public health nutrition (9).

Life cycle assessment (LCA) is a common methodology to assess the environmental impact of food products, covering the entire 'cradle-to-grave' perspective (10-14). The key dimensions are production, manufacturing, transportation, and packaging. On a per kilogram basis, the production of vegetables generally emits less GHG emissions than does the production of meat and dairy products (15). Policy measures that will lead to radical reductions in the consumption of food of animal origin have been proposed as a means to reduce global GHG emissions (16-18).

While discussing the climate impact of food, it is crucial to consider the nutritional value of alternative food choices. It is therefore important to use a functional unit that is relevant from both a nutritional and an environmental perspective. In comparing the cost in 
GHG emissions of producing animal and vegetable foods some past studies have taken only a narrow range of nutrients into account. Such comparisons were based on dietary energy and selected macronutrients such as protein and fat $(14,17)$. However, those studies neither did evaluate protein quality or bioavailability nor did they take into consideration the broad range of vitamins and minerals provided by the different foods. To our knowledge, very few studies have related GHG emissions to the full nutrient contribution of different animal and plant foods.

The technique of nutrient profiling, adopted by leading regulatory agencies worldwide $(19,20)$ is one approach to calculating the full nutrient content of foods. Nutrient profile models provide a single measure of the overall nutritional quality of individual food items, whole meals, or total diets, based on a broad range of macronutrients, vitamins, and minerals $(21,22)$. The intent is to distinguish foods and beverages that are energy dense from those that are nutrient rich (21). The concept of nutrient density has been applied to the study of associations between diets and health (23), food choices in relation to costs (24), and for the creation of front-ofpack symbols and other logos to help consumers select healthy foods at point of sale $(21,23)$.

Nutrient profiling of foods has never before been applied to the study of GHG emissions in relation to climate change. In this article, we explore whether nutrient densities of beverages can mitigate or offset their cost in GHG emissions. We do this by estimating, in a life cycle perspective, the GHG emissions resulting from the production of milk, a soft drink, orange juice, beer, wine, bottled carbonated water, soy drink, and oat drink. Tap water, milk, soft drink, orange juice, beer, wine, and bottled carbonated water are most frequently consumed with meal beverages in Sweden. Beverages based on soy and oat have been suggested as vegetable alternatives to milk, and were therefore also included (25). The nutrient density of the beverages was based on calculations including protein, carbohydrates, fat and 18 vitamins, and minerals. The profiling model reflected the proportion of daily nutrient requirements and the contribution of each nutrient to the Swedish diet. The nutrient density of each beverage was then combined with the GHG emissions to create the novel Nutrient Density to Climate Impact (NDCI) index. Beverages with the highest NDCI index values were those with the highest nutrient density scores in relation to the GHG emissions. Although the report is based on Swedish perspectives concerning the nutrient recommendations and guidelines and GHG emissions, the principle that nutrient density of beverages and foods be considered in the context of climate change is equally applicable worldwide.

\section{Materials and methods}

Beverages

Other than tap water, beverages that are most frequently consumed with meals in Sweden are milk, soft drinks, juices and fruit drinks, beer (2.25-3.5 vol.\% alcohol), wine, and bottled carbonated water $(25,26)$. The climate impact of tap water in Sweden is minimal, so the present calculations were based on the remaining beverages. Soy and oat drinks were also included. From a climate perspective, foods of vegetable origin have been suggested as preferable to foods of animal origin (27).

\section{Nutrient composition of beverages}

The nutrients included in the present study were the ones specified by the Nordic Nutrition Recommendations (NNR) (28) and that also were included in the food database of the Swedish National Food Administration (29). These nutrients were protein, carbohydrates, fat, retinol equivalents, vitamin $\mathrm{D}$, vitamin $\mathrm{E}$, thiamin, riboflavin, ascorbic acid, niacin equivalents, vitamin $\mathrm{B}_{6}$, vitamin $\mathrm{B}_{12}$, folate, phosphorus, iron, potassium, calcium, magnesium, selenium, zinc, and iodine.

The nutrient contents of the included food items were calculated by using the food database of the National Food Administration (Table 1) (29). The nutrition reference values were based on the 4th edition of the NNR (2004) for fertile sedentary women aged 30 60 years (Table 1) (28).

Data on unfortified products were used in order to minimize error and to enhance generalizability. A number of beverages on the market contain added vitamins and minerals, e.g. fortified milk, soy drink, oat drink, orange juice, and carbonated water. Whereas there is no legislative requirement on fortification of most beverages, Swedish legislation calls for vitamin D fortification of low-fat milk. Vitamin $\mathrm{D}_{3}$ (cholecalciferol) is the form used in fortification of Swedish milk. Moreover, there are uncertainties as to the impact of fortification on climate change. The present calculations were therefore based on unfortified products, and on the most frequently consumed form of each beverage in the case of milk semiskimmed milk $(1.5 \%)$. The impact of the fortification on the NDCI index is explained the Discussion section.

\section{Climate impact of beverages}

The total climate impact of the mix of GHGs emitted in the production of the beverages in this study, i.e. carbon dioxide, methane, and nitrous oxide, was calculated by using an index for each gas. This index, global warming potential $\left(\mathrm{GWP}_{100}\right)$, measured the radiative forcing of a unit mass of a given $\mathrm{GHG}$ in the atmosphere in a 100-year perspective. The $\mathrm{GWP}_{100}$ of carbon dioxide was 1 , methane 25 , and nitrous oxide 
Table 1. Nordic Nutrition Recommendations (NNR), and the nutritional content in of 100 g product (29)

\begin{tabular}{|c|c|c|c|c|c|c|c|c|c|}
\hline & $\mathrm{NNR}^{\mathrm{a}}$ & Milk & Soft drink & Orange juice & $\begin{array}{c}\text { Beer (3.5 vol. \% } \\
\text { alcohol) }\end{array}$ & $\begin{array}{l}\text { Red wine (I2 } \\
\text { vol. \% alcohol) }\end{array}$ & $\begin{array}{l}\text { Mineral } \\
\text { water }\end{array}$ & Soy drink & Oat drink \\
\hline Energy (kJ [kcal]) & - & $199(48)$ & $179(43)$ & $200(48)$ & $166(40)$ & 301 (72) & $0(0)$ & $253(60)$ & $183(44)$ \\
\hline Protein (g) & 71.5 & 3.5 & 0 & 0.7 & 0.4 & 0 & 0 & 2.5 & I.I \\
\hline Carbohydrates (g) & 262 & 5 & 10.5 & 10.6 & 4.6 & 0.8 & 0 & 9.1 & 5.8 \\
\hline Fat (g) & 65.7 & 1.5 & 0 & 0.2 & 0 & 0 & 0 & $\mathrm{I} .5$ & 1.6 \\
\hline Retinol equivalents $(\mu g)$ & 700 & 26 & 0 & 10 & 0 & 0 & 0 & 2 & 0 \\
\hline Vitamin D ( $\mu g)$ & 7.5 & 0.38 & 0 & 0 & 0 & 0 & 0 & 0 & 0 \\
\hline Vitamin E (mg) & 8 & 0.04 & 0 & 0.24 & 0 & 0 & 0 & 0.03 & 0.08 \\
\hline Thiamin (mg) & I.I & 0.04 & 0 & 0.09 & 0 & 0 & 0 & 0.04 & 0.05 \\
\hline Riboflavin (mg) & 1.3 & 0.15 & 0 & 0.03 & 0.02 & 0.02 & 0 & 0.02 & 0 \\
\hline Vitamin C (mg) & 75 & 0 & 0 & 50 & 0 & 0 & 0 & 0 & 0 \\
\hline Niacin equivalents (mg) & 15 & 0.9 & 0 & 0.5 & 0.4 & 0.1 & 0 & 0.5 & 0.3 \\
\hline Vitamin $B_{6}(\mathrm{mg})$ & 1.2 & 0.04 & 0 & 0.04 & 0.03 & 0.02 & 0 & 0.05 & 0 \\
\hline Vitamin $B_{12}(\mu g)$ & 2 & 0.42 & 0 & 0 & 0 & 0 & 0 & 0 & 0 \\
\hline Folate $(\mu g)$ & 400 & 6 & 0 & 30 & 0 & 0 & 0 & 28 & I \\
\hline Phosphorus (mg) & 600 & 93 & 12 & 17 & 22 & 15 & 0 & 39 & 30 \\
\hline Iron (mg) & 15 & 0.04 & 0.03 & 0.2 & 0 & I.I & 0 & 0.4 & 0.5 \\
\hline Potassium (mg) & 3,100 & 165 & 1 & 200 & 26 & 110 & II & 60 & 50 \\
\hline Calcium (mg) & 800 & 117 & 3 & II & 4 & 7 & 2 & 19 & 5 \\
\hline Magnesium (mg) & 280 & 12 & I & II & 10 & 12 & I & 17 & 3 \\
\hline Selenium ( $\mu g)$ & 40 & 1.8 & 0 & 0.2 & 0 & 0.1 & 0 & 0.5 & I \\
\hline Zinc (mg) & 7 & 0.45 & 0.01 & 0.1 & 0 & 0.1 & 0.06 & 0.2 & 0.3 \\
\hline lodine $(\mu g)$ & 150 & 14 & - & - & I & - & 0 & - & - \\
\hline
\end{tabular}

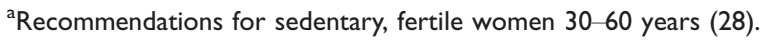

Note: NNR, Nordic Nutrition Recommendations.

310. These values were used in the Kyoto protocol of the International Convention on Climate Change (30). The climate impact of the beverages was expressed in the unit grams of carbon equivalents $\left(\mathrm{CO}_{2} \mathrm{e}\right)$ per 100 grams of beverage (Table 2). This is a common way of handling the combined climate impact of food production $(15,17)$.
The GHG emissions included in this analysis were generated by the following production phases in the life cycle of the beverages:

The production phase at farm level includes emissions related to the crop production including the production of fertilizers and other inputs, feed digestion of the dairy cows and manure storage, fossil fuel usage, and electricity

Table 2. Nutrient density, in relation to climate impact

\begin{tabular}{|c|c|c|c|c|c|}
\hline Food item & Percentage of NNR in $100 \mathrm{~g}$ product & Number of nutrients $\geq 5 \%$ of NNR & Nutrient density & GHG emission & $\mathrm{NDCl}$ index \\
\hline Milk & 126 & 9 & 53.8 & 99 & 0.54 \\
\hline Soft drink & 7 & 0 & 0 & 109 & 0 \\
\hline Orange juice & 90 & 4 & 17.2 & 61 & 0.28 \\
\hline Beer & 18 & 0 & 0 & 101 & 0 \\
\hline Red wine & 24 & 1 & 1.2 & 204 & 0.01 \\
\hline Mineral water & 2 & 0 & 0 & 10 & 0 \\
\hline Soy drink & 53 & 3 & 7.6 & 30 & 0.25 \\
\hline Oat drink & 32 & I & 1.5 & 21 & 0.07 \\
\hline
\end{tabular}

Note: NNR, Nordic Nutrition Recommendations; NDCl index, Nutrient Density to Climate Impact index (NDCl = nutrient density / GHG emission); GHG emission, greenhouse gas emission (grams of $\mathrm{CO}_{2}$ equivalents per $100 \mathrm{~g}$ of product). Nutrient density $=$ Percentage of NNR in $100 \mathrm{~g}$ of product $\times$ Number of nutrients $\geq 5 \%$ of $N N R / 2$. 
production. Transports of all inputs to the farm are also included.

The manufacturing phase includes emissions related to energy use, the use of cooling agents, chemicals, etc. in the industrial processes related to the manufacturing of the beverages studied. The climate impacts from added vitamins were not quantified in any of the beverage LCA-studies, indicating lack of data on emissions from the manufacturing of these components. The climate impact of these additives may or may not be significant and ought to be explored in future studies.

The packaging phase includes emissions related to the manufacturing of the paperboard cartons used for milk, orange juice, oat and soy beverages, as well as of glass bottles used for beer, wine, soft drinks, and bottled carbonated water.

Transportation includes emissions from the transport of crops to the drink manufacturing plants, milk to the dairy, and transports of the packed products to the retailer.

GHG emissions from the consumer phase, including transportation of the beverage from the retailer, storage at home and waste were not included in this study. Neither was GHG emission from the end-of-life of the products included, i.e. from the waste handling of the beverages and the packaging. Changes in soil carbon storage, from cultivation, were not included in the calculations. Carbon sequestration, i.e. the binding of carbon in organic matter in the soil, can be substantial and could reduce the total GHG emissions related to agricultural products (31).

Milk

GHG emissions data for milk were based on a LCAstudy of Swedish milk production (32). The data on GHG emissions at farm level have been confirmed in other detailed life cycle analyses of Swedish milk production $(33,34)$. The GHG emissions from Swedish milk production was very similar to that of other countries, but was in the lower range (35).

Soft drinks

GHG emissions data from a soft drink were based on Coca Cola in a $330 \mathrm{ml}$ recyclable glass bottle (36). The package size and material is common when soft drinks are consumed as a meal beverage in Sweden.

Orange juice

GHG emissions for orange juice were based on juice from a concentrate, sold in Sweden, using a LCA-perspective (37). This study showed that the climate impact of 'fresh' orange juice, i.e. not made from concentrate, was almost three times as high as for orange juice made from concentrate.
Beer and red wine

Emissions for beer and red wine were based on a LCA-analysis of alcohol consumption in the UK, using a top-down approach (38). The beer GHG emissions of the UK top-down study were compared to a more detailed LCA-analysis of an American beer (39), and found similar but slightly lower.

Bottled carbonated water

Emissions data for bottled carbonated water were provided by a Swedish study (40). The bottled carbonated water was packed in a $330 \mathrm{ml}$ recyclable glass bottle, reflecting a common package sizes for bottled carbonated water used as a meal beverage in Sweden.

Soy drink

Emissions data for soy drink were based on two unpublished articles: one from Swedish LCA study where one of the main producers of soy drink in Sweden was used as a reference producer (GHG emission of $33 \mathrm{~g}$ $\mathrm{CO}_{2} \mathrm{e}$ per $100 \mathrm{~g}$ of product), and other from study presented by the same company in the UK $\left(27 \mathrm{~g} \mathrm{CO}_{2} \mathrm{e}\right.$ per $100 \mathrm{~g}$ of product) (41-43). A mean value of the two studies was used in the calculations $\left(30 \mathrm{~g} \mathrm{CO}_{2} \mathrm{e}\right.$ per $100 \mathrm{~g}$ of product).

\section{Oat drink}

Emissions data for oat drink were based on the LCAstudy of a Swedish brand, commonly available in Swedish retailers (44).

There are a number of brands of soy and oat drinks, and different varieties within each brand. Comprehensive composition data on the different products are difficult to find. In the present study, we included products present in the Swedish National Food Administrations food database, which had high quality and large number of nutrients included in, and is publicly available.

\section{Calculation of nutrient density in relation to greenhouse gas (GHG) emission}

Calculations of nutrient density are based on a model described by Drewnowski (21). Twenty-one nutrients were included (Table 1), which were the ones both specified in the NNR (28) and included in the National Food Administration's food database (29). The recommended intake of nutrients is based on the NNR for fertile sedentary women aged 30-60 years (28). Nutrient density of a food item was calculated by summarizing the proportions of recommended daily intake of each nutrient provided by $100 \mathrm{~g}$ of the food item multiplied by the proportion of nutrients contributing to more than $5 \%$ of NNR. The cut-off for significant contribution was set slightly lower than the Codex Alimentarius Commission health claim definition liquid foods as source of nutrients for $7.5 \%$ of recommended intake of a nutrient (45). 
Nutrient density of food item Y

$$
\begin{array}{r}
=\sum_{21 \text { nutr }}\left(100 \times \frac{\text { Amount of nutrient } X \text { in } 100 \mathrm{~g} \text { of } \mathrm{Y}}{\text { Recommended intake of nutrient } \mathrm{X}}\right) \\
\times\left(\frac{\text { Number of nutrients in } \mathrm{Y} \geq 5 \% \text { of rec. intake }}{21}\right)
\end{array}
$$

NDCI index $=\left(\frac{\text { Nutrient density of } \mathrm{Y}}{\mathrm{CO}_{2} \text { e for } 100 \mathrm{~g} \text { of } \mathrm{Y}}\right)$

The Nutrient to Climate Impact (NDCI) index is Nutrient Density divided by the $\mathrm{CO}_{2} \mathrm{e}$ for $100 \mathrm{~g}$ of the food item.

\section{Results and discussion}

\section{Nutrient density in relation to greenhouse gas (GHG) emission}

The NDCI index for milk was substantially higher than for the other beverages studied (Table 2). This can be explained by a very high nutrient density value, both with regard to the number of nutrients and their amount relative to recommendations. Orange juice and soy beverage had similar NDCI index values, but lower than milk (Table 2). The nutrient density of orange juice was higher than that of soy drink, but the GHG emissions were also higher, resulting in a similar index value. Despite low GHG emissions, the NDCI index for oat beverage was very low, reflecting low amounts of many nutrients relative to recommendations. Although many of the beverages studied contained a broad range of nutrients, the amounts present contributed less than 5\% to dietary recommendations.

The present calculations of the NCDI index were based on semi-skimmed milk (1.5\% fat). According to Swedish legislation, low-fat milk ( $1.5 \%$ fat or less) has to be fortified with vitamin D up to $0.38 \mu \mathrm{g} / 100 \mathrm{~g}$. Vitamin $\mathrm{D}_{3}$ (cholecacliferol) is the form of vitamin D used in Swedish milk. In order to investigate how this fortification affects the NDCI index, we calculated a NDCI index for semiskimmed milk with a theoretical vitamin D concentration equal to the concentration of unfortified milk $(0.02 \mu \mathrm{g} /$ $100 \mathrm{~g})$. The NDCI index for theoretically unfortified semi-skimmed milk would be 0.46 (data not shown), which is rather close to the NDCI index for fortified semi-skimmed milk (0.54, Table 2).

The NDCI index included macronutrients, in line with other nutrient density models $(21,24)$. One reason why the present calculations were based on beverage weight as opposed to energy density $(21,24)$ is that the GHG emissions are based on weight, as opposed to calories. On the other hand, the daily dietary recommendations are typically based on 2,000 kcal diet. Thus, by calculating the percent of dietary recommendations for each nutrient, energy of foods was included in the model to some extent.
What is important is that similar calculations were applied to each beverage in turn.

In the NDCI model, $5 \%$ was used as a cut-off level for nutrients with a significant contribution, which is slightly lower than the Codex Alimentarius Commission level of $7.5 \%$. The lower cut-off was chosen in order to make the index more applicable. A $7.5 \%$ cut-off gave the all beverages except milk and orange juice a NDCI index of 0 (data not shown).

\section{The choice of meal beverage}

The beverage is often part of a meal. Since the nutritional content of beverages can differ significantly, the choice of beverage affects the composition of the total meal. Since beverages in general are less satiating than solid foods, the provision of energy containing beverages with meals may increase overall energy intake, potentially leading to weight gain (46). In individuals where positive energy balance is important to avoid, water or more satiating high-protein beverages are preferable [43]. In groups of individuals, such as elderly and children, nutrient dense drinks are preferable. Wine and beer has according to the present investigation low NDCI indexes, contributing with few nutrients to comparatively high GHG emissions, and have primarily a gastronomic role of the meal. The increasing consumption of sweetened caloric beverages has been linked to weight gain among adolescents and adults (46-48). However, continuing studies on long-term consumption and health outcomes are still needed (49). Sweetened beverages provide dietary energy but few nutrients and have a measurable climate impact. The present NDCI index provides a way to reconcile environmental concerns with nutritional recommendations and guidelines (8).

The Swedish National Food Administration recommends a daily intake of $500 \mathrm{~g}$ of low-fat (1.5\% fat or less) milk or corresponding products (50), and an even higher recommendation is found in the USA. (51). The Swedish recommendation concerning milk intake remains after taking into account the effects on the environment of the recommended levels of food consumption (8).

\section{Nutrient content and quality}

Previous studies have investigated total protein content of foods and meals in relation to $\operatorname{GWP}(5,14,17,52)$. Millward and Garnett (52) go one step further and report on single nutrients of different protein sources, discussing the importance of taking this aspect into account when suggesting food choices with lower climate impact. However, we have not found any references where calculations of the comprised estimate of the nutrient content or nutrient density in combination with climate impact. The NDCI index approach takes both nutrient density and climate impact into account in a single index that makes it possible to compare food items. 
The following discussion focuses on the beverages with the highest NDCI indexes, milk, orange juice, and soy drink. Cow's milk and soy drink contained similar amounts of protein, substantially higher than orange juice (Table 1) (29). However, the protein quality must also be taken into consideration. Milk proteins had a more favorable amino acid composition than soy proteins $(8,53)$.

Orange juice and soy drink had substantially higher amounts of carbohydrates than milk. The carbohydrate content of milk was mainly represented by lactose, whereas orange juice contains fructose and soy drink mainly contains starch and disaccharides, of which the majority in soy drink is added sugars (29).

The fat content of the milk and soy drink in this study were the same. Although the fatty acid compositions differed, neither of these beverages with approximately 1.5 and $1.6 \%$ fat, respectively, could be considered as significant sources of fat in the diet.

\section{Policy relevance}

Nutrient density calculations have previously been used in combination with several research areas, as mentioned previously (21-23). In the present study, we combined nutrient density in relation to nutrient recommendations and climate impact. The concept of combining the disciplines nutrition and climate research is entirely novel, and the present study is the first of this kind. There is clearly a need to reconcile environmental and climate concerns with the nutrient density of the diet, using such indices as the NDCI. With increasing frequency, persons and institutions draw conclusions on dietary recommendations from a climate perspective without a comprehensive analysis of nutritional relevance. The NDCI is a comprehensive tool that makes it easier to consider the nutritional aspect of the climate debate.

\section{Nutrition recommendations and dietary guidelines}

A sustainable diet cannot be formulated based only on one or a few aspects but requires taking the complexity of many nutrients into consideration. Particular attention needs to be paid to sources of nutrients for which the recommended amounts of daily intake are difficult to obtain (52). Further, nutrition recommendations must not only fulfil public health goals, but also economic aspects and sustainable development of society. Tools such as the NDCI index are essential to addressing such issues.

\section{Consumption changes in order to decrease climate effects} Changes in consumption patterns are expected to have a significant impact on GHG emissions and have been proposed as a mitigation strategy to reduce climate change globally, e.g. by FAO (6) and UNEP (7). However, we propose that caution must be taken when suggesting changes in food consumption patterns as a means to reduce $\mathrm{GHG}$ emissions. Using a functional unit involving only GWP per kilogram of a food item may lead to the conclusion that vegetable alternatives are always better than those of animal origin.

To our knowledge, the nutrient density has not been taken explicitly into account previously when discussing climate impact of food choices. GHG emissions have not been explicitly studied when making nutrition recommendations. It is thus important to use both knowledge in nutrition and climate to avoid simplistic and erroneous conclusions for food recommendations and dietary guidelines to mitigate climate change.

\section{Uncertainties}

LCA studies of food commonly contain uncertainties in the range $\pm 20-30 \%$ are common (54). This can be explained by large natural variations in GHG emissions from biological systems, such as fields and cows, as well as uncertainties related to model calculations of complex biological and technical systems. In this study, we have no reason to believe that the results from the LCA studies differ in this respect. However, the uncertainties should be taken into account when discussing the results from this study, as well as from other LCA-based studies concerning food and climate impact. Still, results from food item LCA's are useful for comparisons and also for identification of improvement potentials within the production chain (15).

Even if the NDCI index expands the discussion on nutrition and climate impact, it does not encompass the full nutritional spectrum, e.g. the important aspect of macronutrient quality. Nor does it include the important aspect of bioavailability. Although inclusion of these aspects would be interesting, it would make demand a rather complex model.

\section{Future studies}

In order to contribute to discussions on sustainable diets, the contribution in terms of both nutrients and $\mathrm{GHG}$ emissions of a particular food item, such as a meal beverage, should be put in relation to other meal components, as well as to the components of the total diet. The NDCI index can be used to further explore different dietary settings. The figures we use are of the currently best available quality. However, both nutrition and climate research are rapidly developing and more complete data on nutrient composition of food items and more refined LCA-analyses will surely be undertaken. In particular, GHG emissions of fortified drinks will probably be available, enabling comparisons in the future between more nutrient dense beverages. 


\section{Conclusion}

In the present study, we conclude that milk both has the highest nutrient density per se, and has the highest nutrient density in relation to $\mathrm{GHG}$ emissions of the compared beverages. We also conclude that the NDCI index is a tool that facilitates inclusion of a nutritional aspect of the climate debate. Hitherto the nutritional dimensions of how to change food consumption patterns in order to decrease the climate impact have been limited.

\section{Acknowledgements}

Sandra Birgersson and Leif Söderlund, students at KTH Royal Institute for Technology in Stockholm, Sweden, are gratefully acknowledged for providing the unpublished paper on soy drink GHG emissions.

\section{Conflicts of interest and funding}

The authors have no conflicts of interest. AS, HLM and AKME are employed by the Swedish Dairy Association, but AS and HLM are researchers at Uppsala University and Lund University, respectively.

\section{References}

1. IPCC. Climate change 2007: synthesis report; 2008.

2. Swedish Environmental Protection Agency. Konsumtionens klimatpåverkan [The climate impact of consumption]; 2008.

3. European Commission. Environmental impact of products (EIPRO): analysis of the life cycle environmental impacts related to the total final consumption of the EU25. European Commission Technical Report, NO. EUR 22284 EN2006.

4. Girod B, de Haan P. GHG reduction potential of changes in consumption patterns and higher quality levels from Swiss household consumption survey Energy Policy 2009; 37: $5650-61$.

5. Garnett T. Cooking up a storm. Food, greenhouse gas emissions and our changing climate. Guildford, UK: Food Climate Research Network, Centre for Environmental Strategy, University of Surrey; 2008.

6. Steinfeld H, Gerber P, Wassenaar T, Castel V, Rosale M, de Haan C. Livestock's long shadow: environmental issues and option. FAO, Livestock, Environment and Development Initiative Rome. Rome, Italy: FAO; 2006.

7. UNEP (United Nations Environmental Programme). A report of the working group on the environmental impacts of products and materials to the international panel for sustainable resource management. In: Hertwich E, van der Voet E, Suh S, Tukker A, Huijbregts M, Kazmierczyk P, Lenzen M, McNeely J, Moriguchi Y, eds. Assessing the environmental impacts of consumption and production: priority products and materials. Paris: UNEP; 2010.

8. Swedish National Food Administration. The National Food Administration's conclusions from the report towards environmentally aware nutritional recommendations [In Swedish: Livsmedelsverkets slutsatser från underlagsrapporten. På väg mot miljöanpassade kostråd]. Uppsala: Swedish National Food Administration; 2009.
9. Sulda $\mathrm{H}$, Coveney J, Bentley M. An investigation of the ways in which public health nutrition policy and practices can address climate change. Public Health Nutr 2010; 13: 304-13.

10. Berlin J. Environmental life cycle assessment (LCA) of Swedish semi-hard cheese. I Dairy J 2002; 12: 939-53.

11. Avraamides M, Fatta D. Resource consumption and emissions from olive oil production: a life cycle inventory case study in Cyprus. J Cleaner Production 2008; 16: 809-21.

12. Thomassen MA, van alker KJ, Smits MC, Iepema GL, de Boer IJM. Life cycle assessment of milk production systems in the Netherlands. Agricultural Systems 2008; 96: 95-107.

13. Ziegler F, Nilsson P, Mattsson B, Walther Y. Life cycle assessment of frozen cod fillets including fishery-specific environmental impacts. I J Life Cycle Assess 2003; 8: 39-47.

14. Davis J, Sonesson U, Baumgartner DU, Nemecek T. Environmental impact of four meals with different protein sources: case studies in Spain and Sweden. Food Res Int (In press).

15. Sonesson U, Davis J, Ziegler F. Food production and emissions of greenhouse gas emissions. An overview of the climate impact of different production groups. Gothenburg: SIK-the Swedish Institute for Food and Biotechnology; 2010. (Contract No.: 802)

16. Garnett T. Livestock-related greenhouse gas emissions: impacts and options for policy makers. Environ Sci Policy 2009; 12: 491-503.

17. Carlsson-Kanyama A, González AD. Potential contributions of food consumption patterns to climate change. Am J Clin Nutr 2009; 89: 1704S-9S.

18. Goodland R, Anhang J. Livestock and climate change. What if the key actors in climate change are ... cows, pigs, and chickens? World Watch 2009 (November/December): 10-9.

19. Maillot M, Darmon N, Drewnowski A. Are the lowest-cost healthful food plans culturally and socially acceptable? Public Health Nutr 2010; 13: 1178-85.

20. Scarborough P, Arambepola C, Kaur A, Bhatnagar P, Rayner M. Should nutrient profile models be 'category specific' or 'across-the-board'? A comparison of the two systems using diets of British adults. Eur J Clin Nutr 2010; 64: 553-60.

21. Drewnowski A. Concept of a nutritious food: toward a nutrient density score. Am J Clinical Nutr 2005; 82: 721-32.

22. Fulgoni VL 3rd, Keast DR, Drewnowski A. Development and validation of the nutrient-rich foods index: a tool to measure nutritional quality of foods. J Nutr 2009; 139: 1549-54.

23. Miller GD, Drewnowski A, Fulgoni V, Heaney RP, King J, Kennedy E. It is time for a positive approach to dietary guidance using nutrient density as a basic principle. J Nutr 2009; 139: 1198-202.

24. Drewnowski A. The Nutrient Rich Foods Index helps to identify healthy, affordable foods. Am J Clin Nutr 2010; 91: 1095S-1101S.

25. Swedish Board of Agriculture. Agricultural statistics yearbook 2009. 20200226 ed2009. Available from: http://www.sjv.se/om jordbruksverket/statistik/jordbruksstatistiskarsbok/jordbruks statistiskarsbok2009 [cited 20 March 2010].

26. Becker W, Pearson M. Swedish food habits and nutrient intake 1997-98 [In Swedish: Riksmaten 1997-98, Kostvanor och näringsintag i Sverige, Metod- och resultatanalys]. Uppsala: Swedish National Food Administration (Livsmedelsverket); 2003.

27. Carlsson-Kanyama A. Climate change and dietary choices-how can emissions of greenhouse gases from food consumption be reduced? Food Policy 1998; 23: 277-93.

28. Nordic Council of Ministers, editor. Nordic Nutrition Recommendations 2004. Integrating nutrition and physical activity. 4th ed. Århus, Denmark: Nordic Council of Ministers; 2004. 
29. Swedish National Food Administration. National food database [August 2009]. Available from: http://www7.slv.se/livsmedelssok/ [cited 10 February 2010].

30. IPCC. IPCC guidelines for national greenhouse gas inventories, vols. 1-3. London: Intergovernmental Panel on Climate Change; 1996.

31. FAO (Food and Agriculture Organization of the United Nations, Rome, Italy). Review of evidence on drylands pastoral systems and climate change. Implications and opportunities for mitigation and adaptation; 2009. Available from: ftp://fao.org/ docrep/fao/012/i1135e/i1135e00.pdf [cited 25 February 2010].

32. LRF (Federation of Swedish Farmers). Food and environment - LCA of seven food products [In Swedish: Maten och miljön - livscykelanalys av sju livsmedel]. Stockholm, Sweden: Federation of Swedish Farmers; 2002.

33. Cederberg C, Flysjö A. Life cycle inventory of 23 dairy farms in South-Western Sweden. Gothenburg, Sweden: SIK - Swedish Institute for Food and Biotechnology; 2004. (Contract No.: 728)

34. Cederberg C, Flysjö A, Ericson L. Livscykelanalys (LCA) av norrländsk mjölkproduktion [LCA of milk production in northern Sweden]: SIK - the Swedish Institute for Food and Biotechnology 100610. Report Series No. 761; 2007.

35. Sevenster M, de Jong F. A sustainable dairy sector. Global, regional and life-cycle facts and figures on greenhouse-gas emissions. Delft, the Netherlands: CE Delft; 2008.

36. The Coca Cola Company. Corporate responsibility review. London: The Coca Cola Company; 2008.

37. Florén B. Life cycle analysis data on orange juice [In Swedish: LCA-data på apelsinjuice]. Gothenburg, Sweden: SIK - the Swedish Institute for Food and Biotechnology; 2009.

38. Garnett T. The alcohol we drink and its contribution to the UK's greenhouse gas emissions: a discussion paper written at the food climate research network at the Centre for environmental Strategy at University of Surrey; 2007. Available from http://www.fcrn.org.uk/fcrnPublications/publications/PDFs/ Alcohol_paper_2007.pdf [cited 15 February 2010].

39. The Climate Conservancy and the New Belgium Brewing Company. The carbon footprint of fat tire amber ale; 2008. Available from: http://www.newbelgium.com/files/shared/thecarbon-footprint-of-fat-tire-amber-ale-2008-public-dist-rfs.pdf [cited 29 January 2010].

40. Angervall T, Flysjö A, Mattsson B. Comparison of drinking water-an overview life cycle analysis, LCA [In Swedish: Jämförelse av dricksvatten-översiktlig livscykelanalys (LCA)]s. Gothenburg, Sweden: SIK - the Swedish Institute for Food and Biotechnology; 2004.

41. Birgersson S, Karlsson B-S, Söderlund L. Soy Milk - an attributional life cycle assessment examining the potential environmental impact of soy milk. Stockholm, Sweden: Stockholm University; 2009.

42. Alpro Soya. The Alpro sustainable development report 2009. Burton Latimer, UK; 2009. Available from: http://www.natural soya.co.uk/download/ALPRO_SD\%20report_FINAL.pdf [cited 14 June 2010].
43. Ecofys. Alpro Ecofys $\mathrm{CO}_{2}$-emissions report; 2009 Available from: http://jointhemovementnow.org/docs/Alpro_Ecofys_CO2_ emissions_report.pdf [cited 14 June 2010].

44. Dahllöv O, Gustafsson M. Life cycle analysis of Oatly oat drink [In Swedish: Livscykelanalys av Oatly havredryck]. Masters Thesis at the Department of Technology and Society, Environmental and Energy System Studies. Lund, Sweden: Lund University, Department of Technology and Society, Environmental and Energy Systems Studies; 2009.

45. Codex Alimentarius Commission. Nutrition and Health Claims (CAC/GL 23-1997); 1997. Rome, Italy: World Health Organization and the Food And Agriculture Organization of the United Nations. Available from: http://www.codexalimentarius. net/download/standards/351/CXG_023e.pdf [cited 16 June 2010].

46. Dennis EA, Flack KD, Davy BM. Beverage consumption and adult weight management: a review. Eat Behav 2009; 10: 237-46.

47. Nicklas TA, Baranowski T, Cullen KW, Berenson G. Eating patterns, dietary quality and obesity. J Am Coll Nutr 2001; 20: 599-608.

48. Melanson KJ. Lifestyle approaches to promoting healthy eating for children. Am J Lifestyle Med 2008; 2: 26-9.

49. Vartanian LR, Schwartz MB, Brownell KD. Effects of soft drink consumption on nutrition and health: a systematic review and meta-analysis. Am J Public Health 2007; 97: 667-75.

50. Enghardt Barbieri H, Lindvall C. De svenska näringsrekommendationerna översatta till livsmedel. Underlag till generella råd på livsmedels och måltidsnivå för friska vuxna [In Swedish, The Swedish nutritional recommendations translated to food. Basis for general advice on food and meal level for healthy adults]. Uppsala: Swedish National Food Administration; 2003. (Contract No.: 1)

51. U.S. Department of Health and Human Services. Dietary Guidelines for Americans; 2005. Available from: http://www. healthierus.gov/dietaryguidelines [cited 1 March 2010].

52. Millward DJ, Garnett T, editors. Food and the planet: nutritional dilemmas of greenhouse gas emission reductions through reduced intakes of meat and dairy foods. The Summer Meeting of the Nutritional Society. Proceedings of the Nutritional Society. University of Surrey, Guildford; 2009.

53. Bos C, Metges CC, Gaudichon C, Petzke KJ, Pueyo ME, Morens $\mathrm{C}$, et al. Postprandial kinetics of dietary amino acids are the main determinant of their metabolism after soy or milk protein ingestion in humans. J Nutr 2003; 133: 1308-15.

54. FAO (Food and Agriculture Organization of the United Nations). Greenhouse gas emissions from the dairy sector - a life cycle assessment. Rome, Italy: Animal Production and Health Division, FAO; 2010.

\footnotetext{
*Annika Smedman

Unit for Clinical Nutrition and Metabolism

Department of Public Health and Caring Sciences

Uppsala University

Uppsala, Sweden

Tel: +4687905803

Email: annika.smedman@svenskmjolk.se
} 